\title{
Air-Fuel Mixture Temperatures with Light and Heavy Fuels for Effective Spark Ignition Engine Work
}

\author{
V. Raide*, R. Ilves and J. Olt \\ Institute of Technology, Estonian University of Life Sciences, Tartu, Estonia
}

The manuscript was received on 16 April 2021 and was accepted after revision for publication as article paper on 15 December 2021.

\begin{abstract}
:
This research resulted from military interest in finding methods to provide distributed electricity generation in order to support comprehensive state defence measures. The aim of the study was to investigate the effect of a heated air-fuel mixture on the combustion process of a spark ignition (SI) engine, and to highlight the maximum temperatures to be applied to air-fuel mixtures with different fuel fractions in order to avoid any detonation of the fuel mixture in the engine. Tests were carried out with a petrol engine generator (GENSET) so that an investigation could be conducted into the effect of the air-fuel mixture on the engine's combustion. It turned out that heating the air-fuel mixture permits the use of heavier fraction fuels than engine petrol in SI engines does, including diesel fuel and biodiesel fuel, and also that the use of heavy fraction fuels in SI engines is effective mainly under low and middle loads.
\end{abstract}

\section{Keywords:}

combustion, heated air-fuel mixture temperature, heat release rate, spark-ignited heavy fuels

$\begin{array}{ll}\text { Abbreviations } & \\ \text { ABP } & \text { after burning phase } \\ \text { AFM } & \text { air fuel mixture } \\ \text { AFR } & \text { air fuel ratio } \\ \text { ATDC } & \text { after top dead centre } \\ \text { BTDC } & \text { before top dead centre } \\ \text { EF } & \text { ethanol fuel } \\ \text { EP } & \text { engine petrol }\end{array}$

\footnotetext{
* Corresponding author: Chair of Biosystems Engineering, Institute of technology, Estonian University of Life Sciences, Fr.R.Kreutzwaldi 56, EE-51014 Tartu, Estonia. Phone: +372731 33 32, Fax +372 73133 34, E.mail: veljo.raide@baltdefcol.org. ORCID 0000-0002-03765581 .
} 


$\begin{array}{ll}\text { FDP } & \text { flame development phase } \\ \text { FSS } & \text { fuel supply system } \\ \text { GENSET } & \text { electrical generator with combustion engine } \\ \text { HEX } & \text { heat exchanger } \\ \text { HNS } & \text { host nation support } \\ \text { HRR } & \text { heat release rate } \\ \text { ICE } & \text { internal combustion engine } \\ \text { ICT } & \text { information communication technology } \\ \text { Jet } & \text { jet fuel } \\ \text { LoC } & \text { line of supply } \\ \text { MFB } & \text { mass fraction burnet } \\ \text { RBP } & \text { rapid burning phase } \\ \text { RHR } & \text { relative heat release } \\ \text { SI } & \text { spark ignition } \\ \text { TDC } & \text { top dead centre }\end{array}$

\section{Introduction}

According to NATO's own principle, in the event of a military attack its member states must first ensure their own defence capabilities. This requires then to fight with limited resources until comprehensive joint operations can be launched. A full-scale launch of a NATO Article 5 response will take between two to three months. A military invasion is preceded by a gradual escalation into military action, forcing the country to use resources in advance. If those resources have been used prior to the commencement of battle operations and Host Nation Support (HNS) does not have military control of most of the country's territory, Article 5 response will not be launched. Nowadays, the management of state and military operations is based on electricity-consuming ICT (Information Communications Technology), and if there is no energy then there is no management. Regardless of war, peace, emergency, or a crisis situation, distributed ICT systems must be kept operational to ensure national security. Energy security is key, and it requires the production of the required amount of distributed off-the-grid electricity by all possible means. Assets are for peacetime tasks, but crisis reserves are mainly 'national' resources which are in the hands of businesses and individual citizens. The resources for mobile electricity production, independent of wind and the sun, cover engine petrol (EP) generators (GENSET) which can be requisitioned from warehouses, shops, and homes.

A simple and reliable means of generating electricity is a generator which is connected to an internal combustion engine. Small cubic GENSET with a carburettor fuel supply system (FSS) and spark ignition (SI) are widespread. A GENSET with a SI is ten times cheaper than the corresponding compression ignition (CI) engine. The use of EP or ethanol fuel (EF) additive EP only becomes a problem in times of crisis or war, as the fuel supply chains and lines of communication (LoC) are hindered or disrupted. In this case, it must be possible to use a wide variety of fuels in the SI engine, from heavy to light fuels, from fossil fuels to biofuels [1-4], as well as the NATO Single Fuel Concept Jet-A1 (Jet) [5, 6]. Mixtures of biofuels and fossil fuels in any ratio are also considered [7]. The introduction of liquid biofuels continues at an increasing pace, but liquid fossil fuels will certainly be in use for decades to come [8], as a wellfunctioning global production and distribution network has long existed for them [9]. 
An SI engine with a carburettor FSS can use EF, Jet without additives, and CI fuels such as diesel fuel (DF) and hydrogenated vegetable oil (HVO) if the air-fuel mixture (AFM) is heated [10]. The effect of heating heavy fraction fuels in the SI engine has been previously studied in carburettor and injection FSS's. Research [1120] focuses mainly on reducing the hazardous components that are contained within exhaust gases, solving cold start problems, and reducing the engine's fuel consumption rate, as well as on the combustion of various AFM's in the engine's cylinder. In addition, the use of heat energy in different heat exchangers (HEX) is something that has been studied in the past, but the research has focused more on the recovery of heat energy from exhaust gases and the study of cooled exhaust gases [21-28]. It is already accepted that heavy fuels result insufficient quality AFM in the formation of an AFM in an SI piston engine with a carburettor, because the heavy fuel fractions do not evaporate. The combustion of a low-quality AFM in the engine's cylinder is poorer and, as a result, the content of hazardous components $\left(\mathrm{CO}, \mathrm{CO}_{2}, \mathrm{HC}\right.$, and soot $)$ in the exhaust increases, the engine oil gets polluted faster because portions of unburnt fuel enter the engine crankcase from the cylinder walls, and a rich air-fuel mixture results in the early combustion of the air-fuel mixture [29].

In addition, studies have also been conducted in terms of the effect of Jet and biodiesel and diesel fuel blends (20:80) on the small cubic SI engine. It has been found that the carburettor FSS should be replaced by an injection FSS because the carburised AFM is of insufficient quality and, therefore, the FSS is unable to maintain the correct air-fuel ratio (AFR) throughout the load mode of the piston engine [12-14]. The research has not indicated at which AFM temperatures different fuels can be used in the SI engine using the heated AFM method. Due to the different specific properties of the fuels, the AFM for various fuels has to be heated at different temperatures. This is due to several factors such as, for example, the air-fuel equivalence ratio $(\lambda)$ affecting the ignition and combustion of the AFM. In addition, it is important to know what the combustion process is like in the engine when the AFM is being heated to a temperature which is above that at which detonation occurs in the engine. However, when using heavy fraction fuels, it is important to keep the temperature of the AFM as high as possible to ensure fuel evaporation.

The aim of this study was to investigate the effect of a heated AFM on the combustion process for a SI engine, and to identify the maximum temperatures to be used for AFM with different fractions in order to avoid any detonation of the AFM in the engine. In particular, this article analyses the effects of AFM temperatures when using engine petrol (EP), ethanol fuel (EF) (anhydrous), jet fuel Jet A-1 (Jet), diesel fuel (DF), and hydrogenated vegetable oil (HVO) on the SI engine's combustion process. The test subject was a GENSET equipped with a carburettor FSS. The broader aim of the research is to uncover solutions which will help to prevent an energy crisis which could arise in the event of war, emergency, or crisis situation, using different fuels in off-the-shelf petrol engine GENSET's.

\section{Materials and Methods}

\subsection{Setting Up the Test}

The test engine was a GENSET, which was equipped with a carburettor FSS. The maximum allowable load for the electric generator was $2.8 \mathrm{~kW}$. During test preparations, the GENSET was loaded to $2.5 \mathrm{~kW}$, but at this load the engine was able to run at 
$2700 \mathrm{rev} / \mathrm{min}$ only, while the factory speed is $3000 \mathrm{rev} / \mathrm{min}$. To ensure the intended speed mode for the engine, the generator loads were selected to be $2.0 \mathrm{~kW}, 1.5 \mathrm{~kW}$, and $1.0 \mathrm{~kW}$. During the tests, the test engine was loaded with light bulbs. The motor's speed mode is important in terms of it maintaining a stable mains frequency. The technical details for the test engine and test equipment including tested fuels are given in Tab. 1.

Tab. 1 Test equipment and fuels

\begin{tabular}{|c|c|c|c|c|c|c|c|}
\hline \multicolumn{8}{|c|}{ The data of experiment GENSET DB3500CL } \\
\hline Strokes & \multicolumn{2}{|c|}{4} & \multicolumn{4}{|c|}{ Connection rod length } & $84.80 \mathrm{~mm}$ \\
\hline Cylinder & \multicolumn{2}{|c|}{1} & \multicolumn{4}{|c|}{ Swept volume $\left(V_{\mathrm{d}}\right)$} & $207.42 \mathrm{~cm}^{3}$ \\
\hline Displacement & \multicolumn{2}{|c|}{$208 \mathrm{~cm}^{3}$} & \multicolumn{4}{|c|}{ Clearance volume $\left(V_{\mathrm{c}}\right)$} & $28.28 \mathrm{~cm}^{3}$ \\
\hline Engine power & \multicolumn{2}{|c|}{$3.6 \mathrm{~kW}$} & \multicolumn{4}{|c|}{ Total volume $\left(V_{\mathrm{t}}\right)$} & $235.70 \mathrm{~cm}^{3}$ \\
\hline Speed $\left(n_{\mathrm{e}}\right)$ & \multicolumn{2}{|c|}{$3000 \mathrm{rev} / \mathrm{min}$} & \multicolumn{4}{|c|}{ Compression ratio $\left(r_{\mathrm{c}}\right)$} & 8.00 \\
\hline Bore & \multicolumn{2}{|c|}{$70.00 \mathrm{~mm}$} & \multicolumn{4}{|c|}{ Bore to stroke ratio $\left(R_{\mathrm{bs}}\right)$} & 1.29 \\
\hline Stroke $(l)$ & \multicolumn{2}{|c|}{$54.00 \mathrm{~mm}$} & \multicolumn{4}{|c|}{ Connection rod to stroke ratio $(R)$} & 3.14 \\
\hline FSS & \multicolumn{2}{|c|}{ Carburettor } & \multicolumn{4}{|c|}{ Crankshaft radius $(\alpha)$} & $27.00 \mathrm{~mm}$ \\
\hline \multicolumn{8}{|c|}{ The weighing instrument CAS CI2001A } \\
\hline Weight CI-200 & & & & & Measurer & nt accura & cy $\Delta m=1 \mathrm{~g}$ \\
\hline \multicolumn{8}{|c|}{ The combustion pressure measurement system AVL 621} \\
\hline \multicolumn{8}{|c|}{\begin{tabular}{l|l} 
Signal amplifier AVL 2P2E &
\end{tabular}} \\
\hline SI engine press & or ZF4 & & & & Measure & nt accura & cy $1.5 \%$ \\
\hline \multicolumn{8}{|c|}{ The air consumption measurement system AVL } \\
\hline \multicolumn{5}{|c|}{ AVL Flowsonix Air 100} & \multicolumn{3}{|c|}{ Measurement accuracy $< \pm 1 \%$. } \\
\hline \multicolumn{8}{|c|}{ The fuels } \\
\hline Parameter & & Unit & EP* & $\mathrm{EF}^{*}$ & Jet A-1* & $\mathrm{DF}^{*}$ & $\mathrm{HVO}^{*}$ \\
\hline Molecular com & & - & $\mathrm{C}_{5}-\mathrm{C}_{11}$ & $\mathrm{C}_{2}$ & $\mathrm{C}_{7}-\mathrm{C}_{16}$ & $\mathrm{C}_{15}-\mathrm{C}_{23}$ & $\mathrm{C}_{15}-\mathrm{C}_{23}$ \\
\hline Density at $15^{\circ}$ & & $\mathrm{kg} \mathrm{m}^{-3}$ & $700-750$ & 789 & 787 & 765 & $775-785$ \\
\hline Viscosity at 40 & & $\mathrm{~mm}^{2} \mathrm{~s}^{-1}$ & 0.6 & 0.80 & 0.94 & 2.0 & $2.5-3.5$ \\
\hline Octane $^{1}-$ Cetan & & - & $87-97^{1}$ & $108^{1}$ & $30-40^{1}$ & $15-25^{1}$ & $\sim 80-99^{2}$ \\
\hline Boiling point $\mathrm{a}$ & & ${ }^{\circ} \mathrm{C}$ & $25-220$ & 78.37 & $147-230$ & $160-360$ & $269-313$ \\
\hline Flash point & & ${ }^{\circ} \mathrm{C}$ & -45 & 17 & $35-51$ & $50-65$ & 78 \\
\hline Calorific value & & $\mathrm{MJ} \mathrm{kg}^{-1}$ & 43.5 & 26.8 & 43 & 45.4 & 44 \\
\hline AFR & & & $14.6 / 1$ & $9 / 1$ & $15.6 / 1$ & $14.6 / 1$ & $14.6 / 1$ \\
\hline
\end{tabular}

$*[30-42]$

The time taken to measure fuel consumption was seven minutes. Fuel consumption was measured every sixty seconds using a CAS CI2001A weighing instrument. Combustion pressures were measured using an AVL 621 and fifty operating cycles were recorded for each test. Combustion pressures were averaged out, and the heat release rate (HRR) and relative heat release (RHR) were calculated. The heat release rate (HRR), in relation to the rotational angle of the crankshaft, is expressed as follows $[43,44]$ :

$$
\frac{\mathrm{d} Q_{n}}{\mathrm{~d} \varphi}=\frac{\gamma_{\mathrm{hr}}}{\gamma_{\mathrm{hr}}-1} P_{\mathrm{c}} \frac{\mathrm{d} V_{\mathrm{c}}}{\mathrm{d} \varphi}+\frac{1}{\gamma_{\mathrm{hr}}-1} V_{\mathrm{c}} \frac{\mathrm{d} P_{\mathrm{c}}}{\mathrm{d} \varphi}
$$

where $P_{\mathrm{c}}$ - cylinder pressure; $\gamma_{\mathrm{hr}}$ - isentropic exponent; $V_{\mathrm{c}}-$ cylinder volume; $\mathrm{d} \varphi-$ crank angle.

The combustion process was divided into three phases [44]: 1) a flame development phase (FDP); 2) a rapid burning phase (RBP); and 3) an after-burning phase $(\mathrm{ABP})$. The spark angle for the test engine was $48^{\circ} \mathrm{BTDC}$. 
In order to obtain the required reference data, the efficiency and economy parameters for the test engine were first measured at the aforementioned loads. An AFM heating unit was then added to the engine and additional measurements were taken in order that an investigation could be carried out into the effects the unit may be having on the engine's output parameters. The construction and operation of the AFM heating unit are presented below in the form of a separate subsection.

In the tests on different fuels, the temperature of the AFM was raised as high as possible until detonation occurred in the engine cylinder. The temperature of the AFM was then reduced until stable engine operation could be achieved, along with the nondetonated combustion of the AFM. The tests were then carried out. Since the process of heating the AFM serves to change the speed and timing of the combustion phases, the tests were carried out with the heated AFM at a spark angle of $31^{\circ} \mathrm{BTDC}$.

The fuel that was used in the experiment was EP, EF, Jet, DF and HVO. The most important chemical and physical properties of those fuels which were used in the tests are given in Tab. 1, and this is something which must be taken into account when heating the AFM. A carburettor nozzle with a nozzle opening of $0.8 \mathrm{~mm}$ was used for all fuels except EF, for which the nozzle orifice diameter was expanded to $1.2 \mathrm{~mm}$.

\subsection{Operating Principles for the AFM Heating Unit}

To be able to study the effects of the heated AFM, an AFM heating unit based on a process of heat exchange was added to the SI piston engine, which allowed the residual heat energy of the exhaust gases to be transferred into the AFM. The arrangement of the heating unit between the carburettor and the intake manifold is shown in Fig. 1. The cross-sectional area of the AFM channel which was used in the heating unit increases towards the intake manifold due to the expansion of the heated AFM. Tab. 2 reveals the parameters for the most important components of the heat exchanger (HEX) which was added to the FSS.

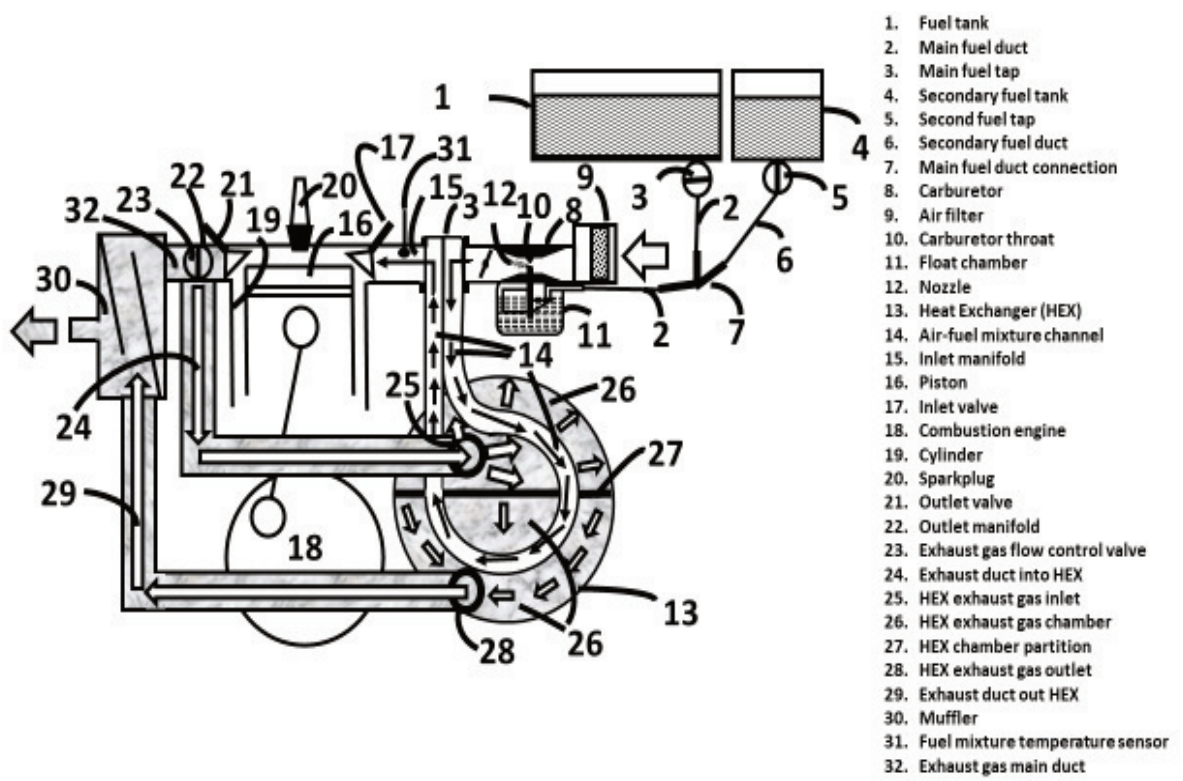

Fig. 1 Schematic diagram of the engine equipped with AFM heating unit 
The air-fuel mixture is directed to the HEX 13 and from the HEX 13, the AFM moves into AFM channel 14, where it is additionally mixed and heated up due to the heat being transferred from the exhaust gases. After that, the additionally-mixed and heated AFM moves from the HEX 13 to intake manifold 15, and from there to the engine. Exhaust gases from the engine are directed either to muffler 30 or the HEX 13, where the heat energy from the exhaust gases is transferred into the AFM. According to the engine load, the temperature of the AFM is regulated by exhaust gas flow control valve 23. If the AFM mixture is not heated, exhaust gas control valve 23 remains in the open position; when heated, valve 23 is in the closed position. To be able to achieve a higher AFM temperature, the exhaust gas flow through the HEX must be increased.

Tab. 2 Basic data of the technical components of heating unit

\begin{tabular}{|l|c|c|}
\hline \multicolumn{1}{|c|}{ Technical component } & Unit & Value \\
\hline HEX AFM channel operating part length & $\mathrm{cm}$ & 21 \\
\hline Cross-sectional area of exhaust gas inlet and outlet ducts & $\mathrm{cm}^{2}$ & 2 \\
\hline The volume of the exhaust chamber of the HEX & $\mathrm{cm}^{3}$ & 400 \\
\hline AFM inlet openings cross-sectional areas & $\mathrm{cm}^{2}$ & 3.15 \\
\hline AFM outlet openings cross-sectional areas & $\mathrm{cm}^{2}$ & 4.7 \\
\hline AFM channel cross-sectional maximum area & $\mathrm{cm}^{2}$ & 6.05 \\
\hline The volume of the HEX AFM channel & $\mathrm{cm}^{3}$ & 100 \\
\hline The HEX AFM channel heated part & $\mathrm{cm}^{3}$ & 80 \\
\hline
\end{tabular}

\section{Results and Discussion}

In the following data tables, the most important data of the experimental environment, are shown, such as carburettor nozzle orifice diameter $\left(A_{\mathrm{n}}\right)$, ambient humidity $(r)$, ambient temperature $\left(t_{\text {env }}\right)$, air-fuel mixture temperature in the inlet manifold (intake), and detonation starting temperature $\left(t_{\text {deto }}\right)$. In addition, the theoretical amount of energy directed into the cylinder per cycle $\left(E_{\text {teor }}\right)$, fuel consumption $\left(B_{\mathrm{f}}\right)$, and air consumption $\left(B_{\mathrm{a}}\right)$ are presented.

Fig. 2 displays the HRR in graphical terms, and Tab. 3 displays the most important details from the test environment and the tests at a load of $1.0 \mathrm{~kW}$. Based on the information contained in Tab. 3, the duration of the FDP using an unheated EP relative AFM is $64^{\circ}$. Fig. 2 shows that the HRR's progress is smooth. The RBP lasts for $68^{\circ}$ and the total duration of the combustion process is $132^{\circ}$. When unheated EF is used, the FDP is $63^{\circ}$ and the RBP is $70^{\circ}$. The duration of the total combustion time for AFM is $133^{\circ}$. Fig. 2 shows that the transition of HRR from one phase to another is smooth. With Jet, the FDP lasts for $65^{\circ}$ and the RBP lasts for $63^{\circ}$. Fig. 2 shows that the HRR's progress is smooth. The total combustion duration is $128^{\circ}$.

$\mathrm{EP}, \mathrm{EF}$ and Jet can be used in an unmodified engine but in case of the Jet, the AFM used is rich due to the high viscosity of the Jet. The high viscosity prevents the fuel from being effectively carburised, and a lean relative AFM prevents the ignition of the AFM in the cylinder because there is not enough evaporated fuel drops in the AFM. Therefore, in order to use Jet more efficiently, it is important to ensure the more efficient evaporation of the fuel. The HRR graph is similar for all fuels because, based on the theory, the combustion efficiency at lambda values of 0.7 to 1.1 is similar. 


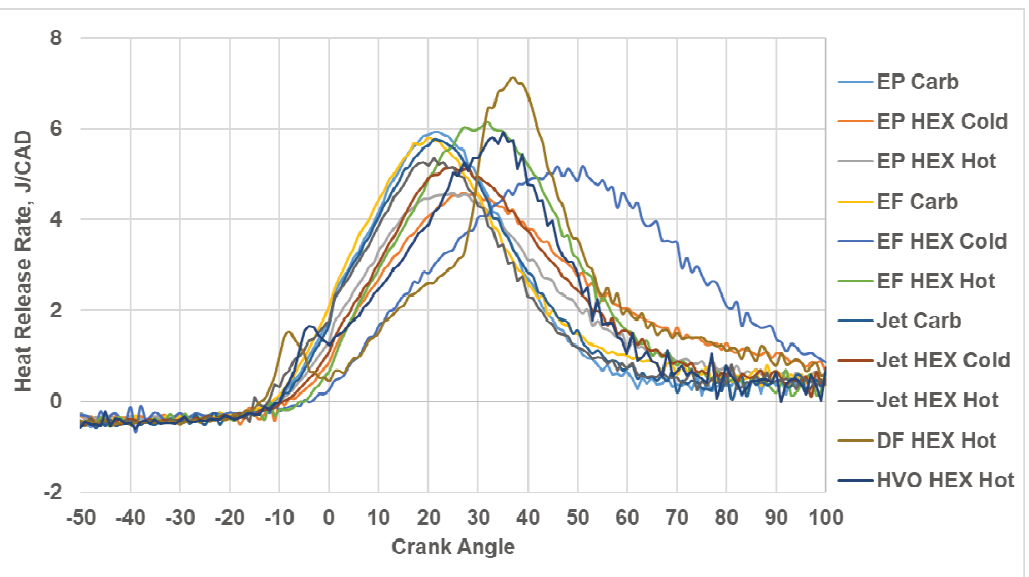

Fig. 2 HRR at load $1.0 \mathrm{~kW}$

Tab. 3 Test data at load $1.0 \mathrm{~kW}$

\begin{tabular}{|c|c|c|c|c|c|c|c|c|c|c|c|c|}
\hline 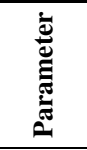 & 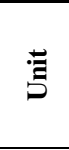 & 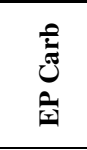 & 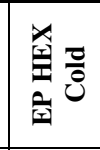 & $\begin{array}{l}x \\
\text { 空 } \\
\text { 产 }\end{array}$ & 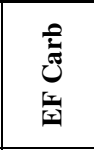 & $\begin{array}{l}x \\
\text { 空 } \\
\text { 空 }\end{array}$ & $\underset{\text { 空 }}{\stackrel{x}{0}}$ & 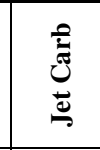 & 远 & 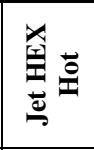 & 离 & $\stackrel{x}{x}^{x}$ \\
\hline$A_{\mathrm{n}}$ & $\mathrm{mm}$ & 0.8 & 0.8 & 0.8 & 1.2 & 1.2 & 0.8 & 0.8 & 0.8 & 0.8 & 0.8 & 0.8 \\
\hline$R$ & $\%$ & 26 & 44 & 44 & 24 & 51 & 30 & 24 & 24 & 24 & 40 & 52 \\
\hline$t_{\mathrm{env}}$ & ${ }^{\circ} \mathrm{C}$ & 24 & 16 & 18 & 22 & 24 & 27 & 21 & 18 & 20 & 26 & 24 \\
\hline$t_{\text {intake }}$ & ${ }^{\circ} \mathrm{C}$ & 26 & 30 & 112 & 33 & 20 & 140 & 13 & 12 & 117 & 120 & 106 \\
\hline$t_{\text {deto }}$ & ${ }^{\circ} \mathrm{C}$ & & & 120 & & & 145 & & & 125 & 125 & 115 \\
\hline BTDC & deg & 48 & 48 & 31 & 48 & 48 & 31 & 48 & 48 & 31 & 31 & 31 \\
\hline$t_{\text {oil }}$ & ${ }^{\circ} \mathrm{C}$ & 81 & 75 & 90 & 77 & 82 & 102 & 74 & 77 & 85 & 74 & 80 \\
\hline$n_{\mathrm{e}}$ & $\mathrm{rpm}$ & 3000 & 2925 & 3011 & 3011 & 3000 & 3000 & 3006 & 2987 & 3025 & 3026 & 3019 \\
\hline$\lambda$ & - & 0.98 & 1.06 & 1.12 & 0.90 & 1.17 & 1.0 & 0.7 & 0.97 & 1.22 & 0.60 & 0.93 \\
\hline$E_{\text {teor }}$ & $\mathrm{J}$ & 286.1 & 317.1 & 278.4 & 312.7 & 303.3 & 294.0 & 394.2 & 280.6 & 217.9 & 523.2 & 379.8 \\
\hline$B_{\mathrm{f}}$ & $\mathrm{kg} / \mathrm{h}$ & 0.56 & 0.62 & 0.54 & 1.01 & 0.98 & 0.95 & 0.83 & 0.59 & 0.46 & 1.10 & 0.80 \\
\hline$B_{\mathrm{a}}$ & $\mathrm{kg} / \mathrm{h}$ & 8.12 & 9.68 & 8.88 & 8.20 & 10.3 & 8.56 & 8.50 & 8.43 & 8.30 & 9.76 & 11.0 \\
\hline FDP & deg & $-48-16$ & $-48-20$ & $-31-17$ & $-48-15$ & $-48-15$ & $-31-21$ & $-48-17$ & $-48-21$ & $-31-16$ & $-31-27$ & $-31-22$ \\
\hline RBP & deg & $17-84$ & $20-100$ & $17-90$ & $16-85$ & $16-85$ & $22-72$ & $18-80$ & $22-83$ & $17-88$ & 28-91 & 23-73 \\
\hline ABP & deg & 85-141 & $101-145$ & $91-139$ & 86-138 & 91-139 & 73-140 & $81-140$ & 84-141 & 89-138 & 92-139 & 74-141 \\
\hline $\begin{array}{l}\text { MFB } \\
10 \%\end{array}$ & deg & 16 & 20 & 17 & 15 & 29 & 21 & 17 & 21 & 16 & 27 & 22 \\
\hline $\begin{array}{l}\text { MFB } \\
50 \%\end{array}$ & deg & 29 & 43 & 35 & 30 & 53 & 37 & 30 & 37 & 30 & 43 & 37 \\
\hline $\begin{array}{l}\text { MFB } \\
90 \%\end{array}$ & deg & 84 & 100 & 90 & 85 & 90 & 72 & 80 & 83 & 88 & 91 & 73 \\
\hline
\end{tabular}


In EP tests with a cold HEX, the FDP is $68^{\circ}$. Fig. 2 shows that the HRR's progress is smooth, although when compared to the test without HEX, the combustion of the AFM takes place at a later point in the process. The RBP lasts for $80^{\circ}$ and the overall combustion duration is $148^{\circ}$. When using EF fuel with a cold HEX, the FDP is $78^{\circ}$. The HRR's progress is smooth and comparable to the use of EP. When compared to a conventional engine test, combustion takes place significantly later. The duration of the RBP is $61^{\circ}$. The general combustion duration of the AFM lasts for $139^{\circ}$. With the Jet, the FDP lasts for $69^{\circ}$. The HRR graph shows that the HRR is steady but is later than with a factory engine setting. The RBP is $62^{\circ}$. The total burning time is $131^{\circ}$. In conclusion, the onset of combustion for the EP AFM with a cold HEX takes place somewhat later and its duration is longer. When using EF, the FDP is nine degrees longer than in an engine which is still using the factory settings, but the RBP is nine degrees shorter. In the case of a cold HEX and a Jet AFM, the combustion process is somewhat later than in an engine which still has its factory settings. When comparing with and without a HEX, it can be seen that the use of a HEX prolongs the FDP and postpones the onset of energy release in the EP and Jet fuel combustion process. This is due to the formation of a leaner AFM in the cylinder. When looking at the MFB50 data in the Tab. 3, it appears that the AFM's ignition and combustion processes are delayed when using all forms of fuel along with a HEX, as compared to the engine which has the factory settings. In theory, the AFM combustion has an MFB50 of $5^{\circ}$ to $7^{\circ}$ ATDC [44]. In the case of the engine that was being tested, delayed combustion is caused by the fact that the spark angle cannot be set for different loads, so instead it is set primarily for high loads being place on the engine.

The combustion of the heated EP AFM has a FDP of $48^{\circ}$ and a RBP of $73^{\circ}$. The conversion of enthalpy to an endothermic exothermic reaction is smooth, and is similar to the results for the cold HEX test. The general combustion phase has a duration of $121^{\circ}$. The heated EF AFM has a FDP of $52^{\circ}$. The RBP phase lasts for $51^{\circ}$. HRR progress is similar to that for the use of EP. However, the maximum value of the HRR is higher when compared to a cold HEX and the use of EF. The total combustion duration is $103^{\circ}$. The heated AFM of Jet has a FDP of $47^{\circ}$ and the RBP is $72^{\circ}$. The total combustion duration is $119^{\circ}$. When compared to a cold AFM of Jet, the combustion duration for the AFM is around twelve degrees shorter. As a result, the timing of the combustion phases has also changed.

The heated DF AFM has a FDP of $58^{\circ}$ and a RBP of $64^{\circ}$. The overall combustion duration is $122^{\circ}$. The values for the HRR graph are significantly higher than for other fuels which were used as a comparison. This can be attributed to the chemical and physical properties of the fuel. Heavy fuel fractions do not burn in the cylinder. At the same time, it is important that enough fuel is directed into the cylinder to ensure the AFM's ignition and combustion in the cylinder. With a heated HVO AFM, the FDP is $53^{\circ}$, the RBP is $51^{\circ}$, and the combustion duration is $104^{\circ}$. When using both $\mathrm{HVO}$ and DF, the HRR graph shows a clear difference in combustion phases, which is something that is characteristic of CI engines. The HRR graph has a premixed combustion phase at -20 to zero degrees of crankshaft rotation for DF, and at -12 to zero degrees for HVO. This is due to the different fuel fractions for the DF and HVO, where the light fractions evaporate and combust rapidly and thereafter the ignition of heavy fractions takes place. In conclusion, fuels with heavy fractions combust somewhat differently in the SI engine when compared to EP and EF. In the DF and HVO combustion process, different phases are formed (the pre-mixed controlled and mixing controlled phases), which are not characteristic of the SI engine. 
Fig. 3 shows the HRR in graphic form, whereas Tab. 4 shows the most important test information for a GENSET load of $1.5 \mathrm{~kW}$.

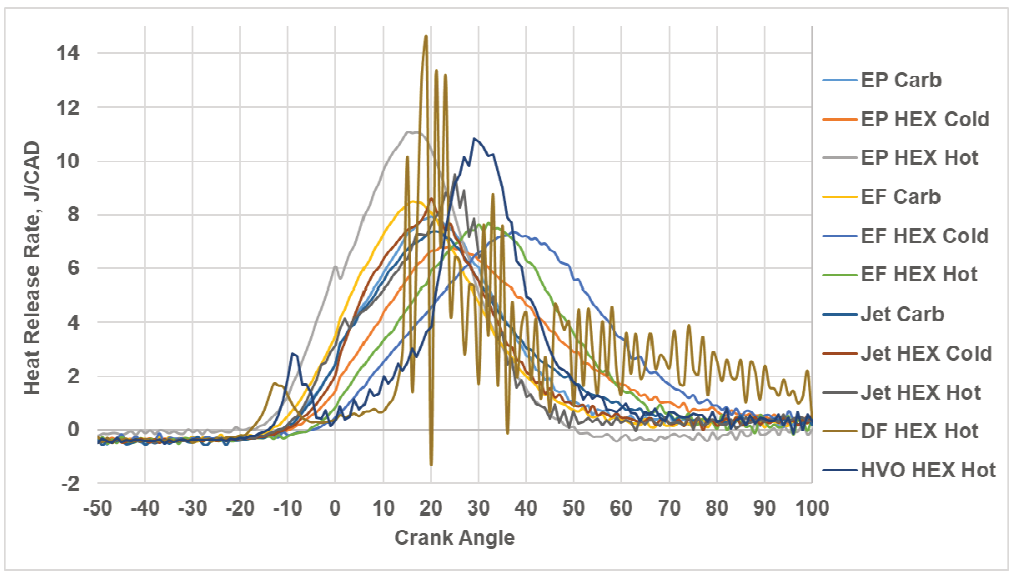

Fig. 3 HRR at load $1.5 \mathrm{~kW}$

Tab. 4 Test data at load $1.5 \mathrm{~kW}$

\begin{tabular}{|c|c|c|c|c|c|c|c|c|c|c|c|c|}
\hline 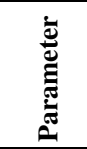 & 站 & 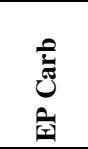 & $\begin{array}{l}x \\
\text { 产 } \\
\text { 言 }\end{array}$ & 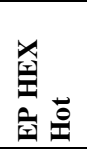 & 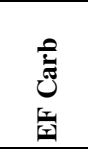 & $\frac{x}{x_{x}}$ & 斑 & 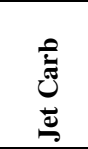 & 递 & 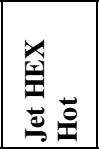 & 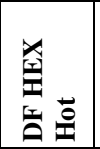 & $\begin{array}{l}x \\
\text { I } \\
0 \\
0\end{array}$ \\
\hline$A_{\mathrm{n}}$ & $\mathrm{mm}$ & 0.8 & 0.8 & 0.8 & 1.2 & 0.8 & 0.8 & 0.8 & 0.8 & 0.8 & 0.8 & 0.8 \\
\hline$r$ & $\%$ & 25 & 45 & 44 & 24 & 51 & 32 & 24 & 24 & 24 & 40 & 35 \\
\hline$t_{\mathrm{env}}$ & ${ }^{\circ} \mathrm{C}$ & 24 & 18 & 18 & 22 & 24 & 26 & 21 & 19 & 20 & 26 & 25 \\
\hline$t_{\text {intake }}$ & ${ }^{\circ} \mathrm{C}$ & 30 & 26 & 107 & 34 & 20 & 100 & 16 & 14 & 61 & 80 & 58 \\
\hline$t_{\text {deto }}$ & ${ }^{\circ} \mathrm{C}$ & & & 115 & & & 110 & & & 68 & 87 & 65 \\
\hline BTDC & deg & 48 & 48 & 31 & 48 & 48 & 31 & 48 & 48 & 31 & 31 & 31 \\
\hline$t_{\mathrm{oil}}$ & ${ }^{\circ} \mathrm{C}$ & 88 & 81 & 91 & 83 & 86 & 104 & 77 & 77 & 88 & 82 & 83 \\
\hline$n_{\mathrm{e}}$ & $\mathrm{rpm}$ & 3008 & 3060 & 2976 & 3019 & 3001 & 3011 & 3026 & 3057 & 3000 & 3020 & 3019 \\
\hline$\lambda$ & - & 0.93 & 1.13 & 0.93 & 0.918 & 1.06 & 1.03 & 0.617 & 1.14 & 1.48 & 0.98 & 0.73 \\
\hline$E_{\text {teor }}$ & $\mathrm{J}$ & 363.5 & 332.5 & 348.0 & 368.7 & 350.0 & 312.7 & 580.5 & 308.2 & 229.3 & 415.7 & 473.0 \\
\hline$B_{\mathrm{f}}$ & $\mathrm{kg} / \mathrm{h}$ & 0.71 & 0.65 & 0.68 & 1.19 & 1.13 & 1.01 & 1.22 & 0.65 & 0.48 & 0.87 & 0.99 \\
\hline$B_{\mathrm{a}}$ & $\mathrm{kg} / \mathrm{h}$ & 9.73 & 10.88 & 9.32 & 9.84 & 10.88 & 9.42 & 11.08 & 10.90 & 10.46 & 12.62 & 10.70 \\
\hline FDP & deg & $-48-11$ & $-48-15$ & $-31-1$ & $-48-8$ & $-48-22$ & $-31-19$ & $-48-12$ & $-48-12$ & $-31-11$ & $-31-18$ & $-31-22$ \\
\hline RBP & deg & $12-58$ & $16-70$ & $2-30$ & $9-51$ & 23-69 & 20-59 & $13-59$ & $13-58$ & $12-59$ & $19-90$ & $23-64$ \\
\hline $\mathrm{ABP}$ & deg & 59-138 & $71-138$ & $31-50$ & $52-136$ & $\mid 70-140$ & $|60-139|$ & $60-135$ & 59-137 & $60-137 \mid$ & 91-141 & $65-139$ \\
\hline $\begin{array}{l}\text { MFB } \\
10 \%\end{array}$ & deg & 11 & 15 & 1 & 8 & 22 & 19 & 12 & 12 & 11 & 18 & 22 \\
\hline $\begin{array}{l}\text { MFB } \\
50 \%\end{array}$ & deg & 25 & 32 & 16 & 21 & 41 & 35 & 27 & 24 & 24 & 42 & 33 \\
\hline $\begin{array}{l}\text { MFB } \\
90 \%\end{array}$ & $\operatorname{deg}$ & 58 & 70 & 30 & 51 & 69 & 59 & 59 & 58 & 59 & 90 & 64 \\
\hline
\end{tabular}


Based on the data in Tab. 4, the duration of the FDP when using an unheated EP AFM is $59^{\circ}$. Fig. 3 shows that the HRR's progress is smooth. The RBP lasts for $47^{\circ}$ and the total combustion process has a duration of $106^{\circ}$. When unheated EF fuel is used, the FDP is $56^{\circ}$ and the RBP is $43^{\circ}$. The overall duration of combustion for the AFM is $89^{\circ}$. Fig. 3 shows that the progress of HRR from one phase to another is smooth. The FDP for Jet lasts for $60^{\circ}$ and the RBP lasts for $47^{\circ}$. Fig. 3 shows that the HRR's progress is smooth. The overall combustion duration is $107^{\circ}$. Combustion with EP and Jet AFM was relatively similar and no major differences in combustion phases were detected. EF differs from test data in terms of rapid combustion and energy release. Due to the high viscosity of Jet, a rich and less volatile fuel mixture with low quality evaporation is formed. Therefore it is important to ensure the more efficient evaporation of the fuel for the more efficient use of the Jet fuel.

In EP tests with a cold HEX, the FDP is $63^{\circ}$. Fig. 3 shows that the HRR's progress is smooth and, when compared to the test without HEX, the combustion of the AFM is delayed. The RBP lasts for $55^{\circ}$ and the overall combustion duration is $118^{\circ}$. When using EF with a cold HEX, the FDP duration is $70^{\circ}$. The progress of HRR is smooth, and is comparable to the use of EP without the HEX test. When compared to the engine with factory settings, combustion is significantly delayed. The duration of the RBP is $47^{\circ}$. The total combustion duration of the AFM lasts for $117^{\circ}$. With the Jet AFM, the FDP lasts for $60^{\circ}$. The HRR graph shows that the rapid energy release is smooth, and is similar to the use of EP and Jet in engine with factory settings. The $\mathrm{RBP}$ is $46^{\circ}$. The overall combustion duration is $106^{\circ}$. The combustion of an EP AFM with a cold HEX is somewhat delayed, and its duration is longer. With an EF AFM, the FDP is $11^{\circ}$ longer than it is when using the engine with factory settings, but the $\mathrm{RBP}$ is of the same length $\left(47^{\circ}\right)$. In the case of a cold HEX and Jet AFM, the combustion process is the same as with the use of EP and Jet in an engine with factory settings. When comparing with and without a HEX, it appears that the use of a HEX prolongs the FDP and postpones the onset of heat release in the combustion process for EP and EF. This is due to the formation of a leaner AFM in the cylinder. When looking at the MFB50 data in the Tab. 4, it appears that the AFM's ignition and combustion take place later when using a HEX with EP and EF, when compared to the results seen in the use of the engine's factory settings. When comparing Jet with tests which use heat exchange and those which do not use heat exchange, the combustion process is similar. In the case of this engine, delayed combustion is caused by the fact that the spark angle cannot be set for different loads, so the spark angle is set according to the optimal loads for the engine. Additional air mixing with Jet in the HEX after carburetting did add combustion efficiency.

The combustion of a heated EP AFM has a FDP of $32^{\circ}$ and a RBP of $29^{\circ}$. The HRR's graph is smooth, but the increase in heat release is sharper when compared to the engine using factory settings. The general combustion phase lasts for $61^{\circ}$. The heated EF AFM has a FDP of $50^{\circ}$. The RBP lasts for $40^{\circ}$. The HRR's progress is similar to EP in an engine with factory settings, but occurs somewhat later. The overall combustion duration is $90^{\circ}$. The heated Jet AFM a FDP of $42^{\circ}$. The RBP is $48^{\circ}$. The overall combustion duration is $90^{\circ}$. For Jet, the combustion duration of the AFM is comparable to that of EF. EP's combustion duration is around $30^{\circ}$ shorter than that of Jet and EF.

The heated DF AFM has a FDP of $49^{\circ}$ and a RBP of $72^{\circ}$. The overall combustion duration is $121^{\circ}$. Fuel consumption is significantly higher than when using other fuels. The progress of the HRR's graph is uneven and the energy release is also uneven. This 
is due to the formation of combustion zones in the AFM. Similar to the light load test, two combustion phases are distinguishable. This can be attributed to the chemical and physical properties of the fuel. With a heated HVO $\left(58^{\circ} \mathrm{C}\right) \mathrm{AFM}$, the FDP is $53^{\circ}$ and the RBP is $42^{\circ}$. The combustion duration is $95^{\circ}$. When using both $\mathrm{HVO}$ and DF, the HRR's graph shows a clear differentiation of combustion phases, which is characteristic of CI engines. For DF, there is an increase in HRR at crank angle degrees of -20 to -5 , and for HVO, the same thing occurs at crank angle degrees of -12 to -3 . This is due to the different fuel fractions of DF and HVO, where the light fractions evaporate and combust rapidly and only thereafter do the heavy fractions ignite.

Heavy fraction fuels burn differently in the SI engine than do EP and EF fuels. In the combustion processes for DF and HVO, differentiable phases are formed (premixed controlled and mixing controlled phases), which are not characteristic of the SI engine. The ignition and combustion of the DF and HVO AFM in the engine's cylinder is rapid and the heat release is short. The differences in the combustion processes of DF and HVO are due to the temperature of the AFM. Because HVO's cetane number is significantly higher when compared to DF, the HVO AFM cannot be heated as much as the DF AFM can. At the same time, the high cetane figure for the fuel improves the duration of the combustion process and the release of heat, which means that HVO releases energy evenly during the combustion process. The combustion of DF is uneven and cyclic when compared to HVO fuel. Based on the available data, no tests were carried out with DF and HVO fuel at a load of $2.0 \mathrm{~kW}$ because detonating combustion would take place in the cylinder at this spark angle. To be able to use DF and HVO at higher loads, an additional setting of the spark angle is necessary in order to prevent detonation during the combustion of the AFM. In the case of EP and EF, heating the AFM makes it possible to change the timing of the combustion phases and therefore to slightly improve the combustion efficiency of the AFM.

Fig. 4 shows a graphic representation of the HRR, while Tab. 5 shows the most important test information for a GENSET load of $2.0 \mathrm{~kW}$.

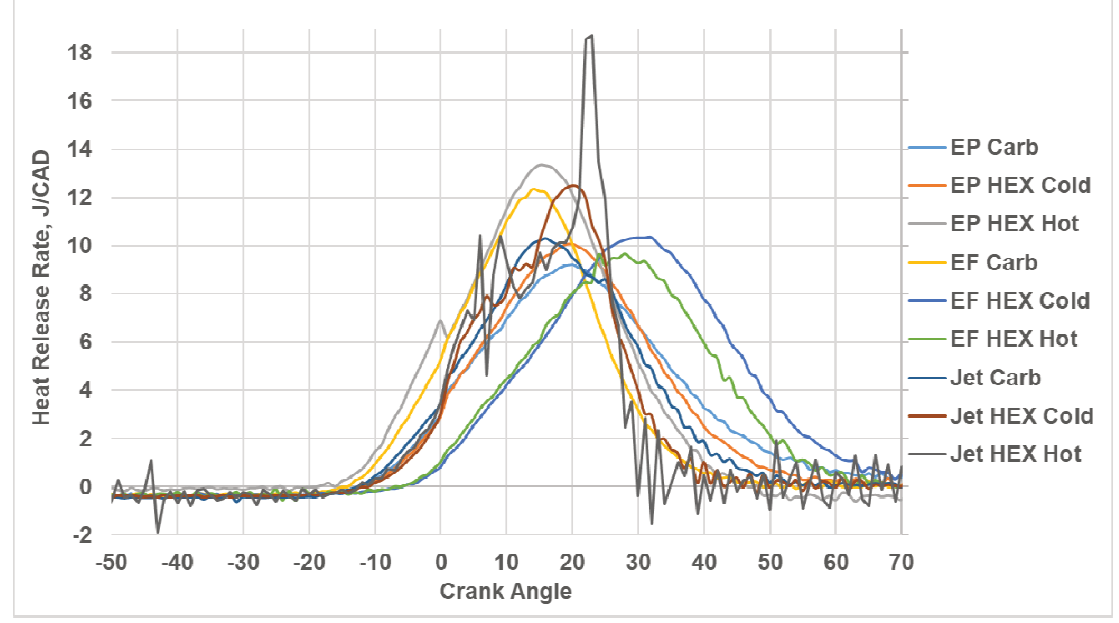

Fig. 4 HRR at load $2.0 \mathrm{~kW}$

Based on the data in Tab. 5, the duration of the FDP when using an unheated EP AFM is $56^{\circ}$. Fig. 4 shows that the progress of HRR is smooth. The RBP lasts for $40^{\circ}$ and the total combustion process has a duration of $96^{\circ}$. When using unheated HEX 
and EF, the FDP is $53^{\circ}$ and the RBP is $27^{\circ}$. The overall duration of combustion for the AFM is $80^{\circ}$. Fig. 4 shows that the transition of HRR from one phase to another is smooth. The FDP for Jet lasts for $56^{\circ}$, and the RBP lasts for $30^{\circ}$. Fig. 4 shows that the progress of HRR is smooth. The overall combustion duration is $96^{\circ}$. Jet can be used in an unmodified engine, but the AFM is rich, which is due to the high viscosity of Jet. High viscosity prevents the efficient carburisation of the fuel, and a lean AFM prevents the ignition of the AFM in the cylinder because the AFM does not contain enough evaporated fuel. Different AFM's burned stably in the engine.

Tab. 5 Test data at load $2.0 \mathrm{~kW}$

\begin{tabular}{|c|c|c|c|c|c|c|c|c|c|c|}
\hline 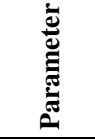 & 泀 & 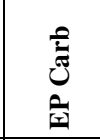 & 홍 & 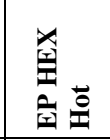 & 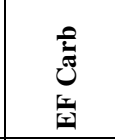 & 홍 & 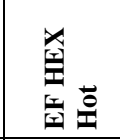 & 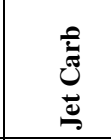 & 홓 & $\stackrel{x}{\underline{x}}$ \\
\hline$A_{\mathrm{n}}$ & $\mathrm{mm}$ & 0.8 & 0.8 & 0.8 & 1.2 & 1.2 & 1.2 & 0.8 & 0.8 & 0.8 \\
\hline$r$ & $\%$ & 25 & 46 & 45 & 24 & 51 & 31 & 24 & 24 & 24 \\
\hline$t_{\text {env }}$ & ${ }^{\circ} \mathrm{C}$ & 24 & 18 & 18 & 24 & 24 & 26 & 21 & 19 & 20 \\
\hline$t_{\text {intake }}$ & ${ }^{\circ} \mathrm{C}$ & 23 & 23 & 42 & 26 & 37 & 50 & 23 & 30 & 35 \\
\hline$t_{\text {deto }}$ & ${ }^{\circ} \mathrm{C}$ & 32 & 28 & 53 & 33 & 18 & 50 & 16 & 13 & 45 \\
\hline BTDC & deg & 48 & 48 & 48 & 48 & 31 & 31 & 48 & 48 & 48 \\
\hline$t_{\text {oil }}$ & ${ }^{\circ} \mathrm{C}$ & 93 & 85 & 90 & 86 & 87 & 105 & 78 & 82 & 85 \\
\hline$n_{\mathrm{e}}$ & $\mathrm{rpm}$ & 3009 & 2945 & 2986 & 3004 & 3014 & 3038 & 3038 & 3095 & 3085 \\
\hline$\lambda$ & - & 0.87 & 1.13 & 0.86 & 0.84 & 1.13 & 1.03 & 0.68 & 1.129 & 1.4 \\
\hline$E_{\text {teor }}$ & $\mathrm{J}$ & 425.3 & 348.0 & 425.3 & 448.0 & 354.7 & 374.3 & 587.7 & 365.5 & 293.8 \\
\hline$B_{\mathrm{f}}$ & $\mathrm{kg} / \mathrm{h}$ & 0.83 & 0.68 & 0.83 & 1.44 & 1.14 & 1.20 & 1.23 & 0.77 & 0.62 \\
\hline$B_{\mathrm{a}}$ & $\mathrm{kg} / \mathrm{h}$ & 10.66 & 11.30 & 10.58 & 10.94 & 11.68 & 11.16 & 12.34 & 12.79 & 12.79 \\
\hline FDP & deg & $-48-8$ & $-48-9$ & $-31-17$ & $-48-15$ & $-48-15$ & $-31-16$ & $-48-8$ & $-48-8$ & $-31-8$ \\
\hline $\mathrm{RBP}$ & deg & $9-48$ & $10-42$ & $17-29$ & $16-85$ & $16-85$ & $17-47$ & $9-38$ & $9-33$ & $9-31$ \\
\hline $\mathrm{ABP}$ & deg & 49-139 & $43-140$ & $30-48$ & 86-138 & $91-140$ & $48-139$ & $39-138$ & $34-138$ & $32-130$ \\
\hline $\begin{array}{l}\text { MFB } \\
10 \%\end{array}$ & deg & 8 & 9 & 1 & 5 & 17 & 16 & 8 & 8 & 8 \\
\hline $\begin{array}{l}\text { MFB } \\
50 \%\end{array}$ & deg & 23 & 22 & 15 & 16 & 32 & 30 & 20 & 19 & 19 \\
\hline $\begin{array}{l}\text { MFB } \\
90 \%\end{array}$ & deg & 48 & 42 & 29 & 32 & 53 & 47 & 38 & 33 & 31 \\
\hline
\end{tabular}

In EP tests with a cold HEX, the FDP is $57^{\circ}$. Fig. 4 shows that the progress of the HRR is smooth, and it is similar to the factory settings for the engine (using EP). The RBP lasts for $33^{\circ}$ and the overall duration of combustion is $90^{\circ}$. When using EF, the duration of the FDP is $65^{\circ}$ when applying a cold HEX. The progress of HRR is smooth, but when compared to the factory settings for the engine, combustion occurs significantly later. The RBP lasts for $36^{\circ}$. The duration of general combustion for the AFM is $101^{\circ}$. With a Jet AFM, the FDP lasts for $56^{\circ}$. The graph for the HRR shows 
that heat release is steady but more rapid when compared to the engine's factory settings. The RBP lasts for $25^{\circ}$. The overall combustion duration is $81^{\circ}$. The combustion process for an EP and Jet AFM with a cold HEX is similar to that for the engine when using the factory settings. With EF fuel, the FDP is $10^{\circ}$ longer than in an engine with the factory settings, but the RBP is $4^{\circ}$ shorter. When looking at the MFB50 data in the table (Tab. 5), it appears that the EP and Jet values are similar when compared to the factory settings and to the cold HEX tests. The ignition and combustion of the EF AFM are both late when using a HEX, when compared to the results with the engine with factory settings.

The combustion of the heated EP AFM $\left(53{ }^{\circ} \mathrm{C}\right)$ has a FDP of $32^{\circ}$ and a RBP of $28^{\circ}$. The progress of the HRR is smooth. The general combustion duration lasts for $60^{\circ}$. With the heated EF AFM $\left(50{ }^{\circ} \mathrm{C}\right)$, the FDP is $47^{\circ}$. The RBP lasts for $31^{\circ}$. The HRR progresses smoothly. The overall combustion duration is $78^{\circ}$. The heated Jet AFM has a FDP of $39^{\circ}$ and the RBP is $23^{\circ}$. The overall combustion duration is $62^{\circ}$. The progress of HRR is uneven and a sudden release of energy occurs in the range of 20-25 CAD in the combustion process, which characterises detonating combustion in the cylinder. Therefore it is recommended that the spark angle of the engine be set somewhat later to ensure a more stable heat release in the cylinder. Based on MFB50 data, heating the AFM accelerates the FDP and the RBP in the combustion process of the fuels.

The above results show that the use of heavy fuel fractions in the SI engine is effective mainly at low and medium loads. At high loads, the combustion of fuels causes problems due to the chemical and physical properties of the heavy fuel fractions.

The preheating system allows to use different fuels in the spark ignition engine, but in practical use, following aspects are important:

- the combustion of the heated fuel mixture is faster and the ignition timing needs to be delayed, which depends on the used fuel,

- when diesel fuel is used, the fuel flow must be limited,

- in order to control the heated fuel mixture temperature accurately, the heat exchanger must be isolated.

\section{Conclusions}

In the course of the research, tests were carried out in order to see the effect of a heated AFM on the SI engine's combustion process. Heating the AFM permits the use of heavy fraction fuels in SI engines, such as diesel or biodiesel. The engine tests were carried out and the results were as follows:

At a load of $1 \mathrm{~kW}$ : In the unmodified engine, Jet can be used in addition to EP and EF, but the AFM is rich under such circumstances, which is due to the high viscosity of Jet. High viscosity prevents the efficient carburisation of the fuel, and a lean AFM prevents the ignition of the AFM in the cylinder because the AFM does not contain enough evaporated fuel. Therefore, in order to use Jet more efficiently, it is important to ensure the more efficient evaporation of the fuel. The onset of the combustion of the EP AFM with a cold HEX occurs later and its duration is longer. With $\mathrm{EF}$, the FDP is nine degrees longer than in an engine which is still using the factory settings, but the RBP is $9^{\circ}$ shorter. In the case of a cold HEX and a Jet AFM, the combustion process takes place somewhat later than it does in an engine which has its factory settings intact. When comparing systems with and without a HEX, it can be seen that the use of a HEX prolongs the FDP and postpones the onset of heat release in 
the combustion process when using EP and Jet. This is due to the formation of a lean AFM in the cylinder. Based on the MFB50 data, it appears that the AFM's ignition and combustion phases are delayed with all fuels when using a HEX, when compared to an engine with its factory settings. In the case of the engine that was tested, delayed combustion is caused by the fact that the spark angle cannot be set for different loads, so the spark angle had to be set for high engine loads alone.

When comparing the tests between hot and cold EP and EF AFM's, the use of a heated AFM serves to delay combustion. This is due to the use of a leaner AFM when heating. When compared to the tests that were carried out with a hot and cold Jet AFM, the combustion duration of the AFM is about $12^{\circ}$ shorter. Consequently it can be concluded that the timing of the combustion phases changes when the AFM is heated. Heavy fraction fuels burn somewhat differently in the SI engine than they do with the EP and EF fuels. In the combustion process for DF and HVO, differentiable phases are formed (in the premixed controlled and mixing controlled phases), which are not characteristic of the SI engine.

At a load of $1.5 \mathrm{~kW}$ : In the case of an engine with a normal setting, the combustion of EP and Jet AFM's is relatively similar and no major differences were detected in combustion phases. In the test data, EF is characterised by faster combustion and heat release. Due to the high viscosity of Jet, a rich and less volatile AFM is formed. Therefore, in order to use Jet more efficiently, it is important to ensure a more efficient evaporation of the fuel. The combustion start of EP with a cold HEX takes place later and lasts longer. With EF, the FDP is $11^{\circ}$ longer than it is in an engine which is using the factory settings, but the rapid-burning phase has the same length $\left(47^{\circ}\right)$. In the case of a cold HEX and a Jet AFM, the combustion process is similar to the use of EP and Jet in an engine with factory settings. When comparing the systems with and without a HEX, it appears that the use of a HEX prolongs the FDP and postpones the onset of heat release in the combustion process using EP and EF. This is due to the formation of a leaner AFM in the cylinder. Based on MFB50 data in the table, it appears that the AFM's ignition and combustion are delayed with EP and EF when using a HEX, when compared to the engine with factory settings. When comparing Jet with and without a HEX, the combustion process is similar. In the case of the engine that was tested, delayed combustion is caused by the fact that the spark angle cannot be set for different loads, so the spark angle has to be set for optimum engine loads instead. Additional AFM with Jet fuel after carburetting in a HEX added combustion efficiency. This is also confirmed by the value of the $\lambda$, which is significantly higher when compared to the test without a HEX.

For Jet, the combustion duration of the heated AFM is comparable to that of EF fuel. EP's combustion duration is around $30^{\circ}$ shorter than that of Jet and EF. Heavy fraction fuels combust differently in the SI engine at this load when compared to EP and EF fuels. In the combustion process for DF and HVO, differentiable phases are formed (premixed controlled and mixing controlled phases), which are not characteristic of the SI engine. The ignition and combustion of DF and HVO AFM in the engine's cylinder are rapid, and the heat release phase is short. The differences in the combustion processes for DF and HVO are due to the temperature of the AFM. As the cetane figure for HVO is significantly higher than that of DF, the HVO AFM cannot be heated as much as the DF AFM can. At the same time, the high cetane figure for the fuel improves the speed of the combustion process and the heat release, so that HVO releases heat evenly during its combustion. The combustion of DF is uneven and cyclic by comparison with HVO. Based on the data, no tests were carried out with DF 
and HVO fuel at a load of $2.0 \mathrm{~kW}$ because detonating combustion would take place in the cylinder at such a spark angle. To use DF and HVO at higher loads, an additional setting of the spark angle is necessary in order to prevent any detonation during the combustion of the AFM. In the case of EP and EF, heating the AFM makes it possible to change the timing of the combustion phases and thereby to slightly improve the combustion efficiency of the AFM.

At a load of 2 kW: Jet fuel can be used in an unmodified engine, but the fuel mixture used is rich, which is due to the high viscosity of Jet. High viscosity prevents the fuel from being effectively carburised, and a lean AFM prevents the ignition of the AFM in the cylinder because the AFM does not contain enough evaporated fuel. Different AFM-s burned stably in the engine. The combustion process for an EP and Jet AFM with a cold HEX is similar to that of the engine with the factory settings. With $\mathrm{EF}$, the FDP is $10^{\circ}$ longer than it is in an engine which has the factory settings, but the RBP is $4^{\circ}$ shorter. Based on MFB50 data, it appears that the values for EP and Jet are similar to those of the factory settings and the cold HEX tests. The ignition and combustion of the EF AFM are delayed when using a HEX, in comparison with the engine at its factory settings. With the heated Jet AFM, the HRR's progress is uneven and there is a sudden release of heat in the combustion process, which illustrates a detonating combustion in the cylinder. Therefore it is recommended that the engine's spark angle be set somewhat later to ensure a more stable heat release in the cylinder. Based on MFB50 data, the heating of the AFM accelerates the FDP and the RBP in the combustion process for the fuels.

\section{Acknowledgement}

This article was funded by the Estonian Defence Forces under the agreement between the Estonian Defence Forces and the Estonian University of Life Sciences No 04062015-880.

\section{References}

[1] KÜÜT, A., R. ILVES, V. MIKITA and J. OLT. Cost of Ethanol when Used in Diesel Engine. In: Proceedings of the $11^{\text {th }}$ International Scientific Conference Engineering for Rural Development. Jelgava: Latvia University of Agriculture, 2012, 11, pp. 366-371. ISSN 1691-3043.

[2] KÜÜT, A and J. OLT. Use of Bioethanol Fuel as Regular Fuel. Actual Tasks on Agricultural Engineering, 2010, 38, pp. 291-298. ISSN 1333-2651.

[3] ILVES, R. and J. OLT. Influence of the Drop Size of Bioethanol Fuel in AirFuel Mixture on Combustion Process of Spark Ignition Engine. Agronomy Research, 2014, 12(2), pp. 341-350. ISSN 1406-894X.

[4] ILVES, R. and J. OLT. Study of Prior Art of Spark Ignition Engine Fuel Supply System. Agronomy Research, 2012, 10(1), pp. 55-74. ISSN 1406-894X.

[5] LE PERA, M.E. The Reality of the Single-Fuel Concept [online]. [viewed 202010-11]. Available from: https://www.globalsecurity.org/military/library/report/ 2005/050300-concept.htm 
[6] Fuels, Oils, Lubrications and Petrol Handling Equipment. In: NATO Logistic Handbook [online]. 1997 [viewed 2020-10-21]. Available from: https://www.nato.int/docu/logi-en/1997/lo-15a.htm

[7] RASLAVIČIUS, L. and D. MARKŠAITIS. Research into Three-Component Biodiesel Fuel Combustion Process Using a Single Droplet Technique. Transport, 2007, 22(4), pp. 312-315. DOI 10.3846/16484142.2007.9638147.

[8] AllabBAD, M., G. ISSAYEV, J. BADRA, A.K. VOICE, B.R. GIRI, K. DJEBBI, A. AHMED, S.M. SARATHY and A. FAROOQ. Autoignition of Straight-Run Naphtha: a Promising Fuel for Advanced Compression Ignition Engines. Combustion and Flame, 2018, 189, pp. 337-346. DOI: 10.1016/j.combustflame.2017.10.038.

[9] HOPPE, F., B. HEUSER, M. THEWES, F. KREMER, S. PISCHINGER, M. DAHMEN, M. HECHINGER and M. WOLFGANG. Tailor-Made Fuels for Future Engine Concepts. International Journal of Engine Research, 2016, 17(1), pp. 16-27. DOI 10.1177/1468087415603005.

[10] RAIDE, V., R. ILVES, K. KÜÜT and J. OLT. Development of Heat Exchange Reactor for Preparation of Air-Fuel Mixture in Spark Ignition Engine. In: Proceedings of the $17^{\text {th }}$ International Scientific Conference Engineering for Rural Development, 2018, 17, pp. 2040-2047. DOI 10.22616/ERDev2018.17.N247.

[11] MODA, S.U.S. Computional Modeling and Analysis of Heavy Fuel Feasibility in Direct Injection Spark Ignition Engine [Thesis]. Dayton: Wright State University, 2011.

[12] GROENEWEGEN, J.R.J. The Performance and Emissions Characteristics of Heavy Fuels in a Small, Spark Ignition Engine [Thesis]. Dayton: University of Dayton, 2011.

[13] GARIPOV, M., J. SAKULIN and R. REZVANOV. Characteristics of a Spark-Ignition Two-Stroke Engine with Diesel Fuel. Journal UGATU, 2017, 2(76), pp. 30-41.

[14] FALKOWSKI, T., D.L. ABATA and P. CHO. The Performance of a SparkIgnited Stratified-Charge Two Stroke Engine Operating on a Kerosine Based Aviation Fuel. In: SAE International Off-Highway and Powerplant Congress and Exposition. Houghton: Michigan Technological University, 1997. DOI $10.4271 / 972737$.

[15] MAHMOUDZADEH, A.M., A. PESYRIDIS, V. ESFAHANIAN and M.F.M. SAID. Combustion and Emission Enhancement of a Spark Ignition Two-Stroke Cycle Engine Utilizing Internal and External Exhaust Gas Recirculation Approach at Low-Load Operation. Energies, 2019, 12(4), pp. 609. DOI 10.3390/en12040609.

[16] SHANMUGHASUNDARAM, P., V. GOPINATH and P. SURESH. Performance and Emission Characteristics of a Diesel Engine Fuelled by Corn Oil Biodiesel Blends with Air Pre-Heater. Mechanical Technologies, 2017, 23(3), pp. 462-468. DOI 10.5755/j01.mech.23.3.14853.

[17] SHARMA, V., J.M. BABU, R. NARESH, S. GOWTHAMAN and R. MARIAPPAN. Design and Fabrication of Air Preheater for Diesel Engine. In: BAJPAI R.P., U. CHANDRASEKHAR and A.R. ARANKALLE, ed. Innovative 
Design, Analysis and Development Practices in Aerospace and Automotive Engineering, New Delhi: Springer, 2014, pp. 261-267. ISBN 978-81-322-1871-5.

[18] KASTURI, M.L., A.S. PATIL, N.P. SHINDE and P.R. JAGTAP. Effect of Inlet Air Preheating on Exhaust Gases in Single Cylinder I.C Engine. International Research Journal of Engineering and Technology, 2017, 4(7), pp. 55-58. DOI 10.13140/RG.2.2.12523.23846.

[19] GHALY, A.M., Y.A. ELDRAINY, W.M. EL-MAGHLANY and A.M. YOUSEF. Novel Thermal Throttling Model in Spark Ignition Engines: A Way to Replace a Mechanical One. Thermal Science and Engineering Progress, 2017, 4, pp. 223-230. DOI 10.1016/j.tsep.2017.10.012.

[20] GUPTA, M., P.P.R. AGARWAL and S. DEBANJAN. Design and Review of Fuel Vaporization System. International Journal of Mechanical Enigeering Research, 2018, 6(2), pp. 5-8. DOI 10.13140/RG.2.2.16561.02401.

[21] DACCORD, R. Cost to Benefit Ratio of an Exhaust Heat Recovery System on a Long Haul Truck. Energy Procedia, 2017, 129, pp. 740-745. DOI 10.1016/j.egypro.2017.09.108.

[22] EFTEKHAR, M. and A. KESHAVARZ. Reducing the Emissions and Fuel Consumption of a Spark Ignition Engine by Utilizing Heat Exchangers in the Exhaust Gas Stream. Journal of Automobile Engineering, 2011, 225(6), pp. 760770. DOI 10.1177/0954407011399824.

[23] LIU, R., M. WEI and H. YANG. Cold Start Control Strategy for a Two-Stroke Spark Ignition Diesel-Fuelled Engine with Air-Assisted Direct Injection. Applied Thermal Engineering, 2016, 108, pp. 414-426. DOI 10.1016/ j.applthermaleng.2016.07.148.

[24] LEE, S. and C. BAE. The Application of an Exhaust Heat Exchanger to Protect the Catalyst and Improve the Fuel Economy in a Spark-Ignition Engine. Journal of Automobile Engieering, 2007, 221(5), pp. 621-628. DOI 10.1243/09544070JAUTO190.

[25] AMICABILE, S., J.I. LEE and D. KUM. A Comprehensive Design Methodology of Organic Rankine Cycles for the Waste Heat Recovery of Automotive Heavy-Duty Diesel Engines. Applied Thermal Engineering, 2015, 87, pp. 574585. DOI 10.1016/j.applthermaleng.2015.04.034.

[26] PIZZONIA, F., T. CASTIGLIONE and S. BOVA. A Robust Model Predictive Control for Efficient Thermal Management of Internal Combustion Engines. Applied Energy, 2016, 169, pp. 555-566. DOI 10.1016/j.apenergy.2016.02.063.

[27] SHAHADAT, M.M.Z., M.N. NABI, M.S. AKHTER and M.S.H.K. TUSHAR. Combined Effect of EGR and Inlet Air Preheating on Engine Performance in Diesel Engine [online]. International Energy Journal, 2008, 9(2), pp. 109-116. [viewed 2020-09-19]. Available from: http://www.rericjournal.ait.ac.th/ index.php/reric/article/view/436

[28] NADAF, S.L. and P.B. GANGAVATI. A Review on Waste Heat Recovery and Utilization from Diesel Engines. International Journal of Advanced Engineering Technology, 2014, 5(4), pp. 31-39. ISSN 0976-3945.

[29] WALKER, D.H., A.C. HARVEY and N.B. LONGO. Fog Carburettor US2010/0170481 A1 [Patent Application Publication] [online]. 2010. [viewed 
2020-09-08]. Available from: https://patentimages.storage.googleapis.com/12/ 6e/1b/a0c7e98860c0a1/US20100170481A1.pdf

[30] ZHAO, J.L., L. ZHOU, Z. ZHAO, X. WANG and F. ZHANG. Research on Knocking Characteristics of Kerosene Spark-Ignition Engine for Unmanned Aerial Vehicle (UAV) by Numerical Simulation. Thermal Science and Engineering Progress, 2019, 9, pp. 1-10. DOI 10.1016/j.tsep.2018.10.014.

[31] AL-ABDUlLAH, M.H., G.T. KALGHATGI and H. BABIKER. Flash Points and Volatility Characteristics of Gasoline/Diesel Blends. Fuel, 2015, 153, pp. 67-69. DOI 10.1016/j.fuel.2015.02.070.

[32] HISSA, M., S. NIEMI, K. SIRVIÖ, A. NIEMI and T. OVASKA. Combustion Studies of a Non-Road Diesel Engine with Several Alternative Liquid Fuels. Energies, 2019, 12(12), 2447. DOI 10.3390/en12122447.

[33] EJIM, C.E., B.A. FLECK and A. AMIRFAZLI. Analytical Study for Atomization of Biodiesels and Their Blends in a Typical Injector: Surface Tension and Viscosity Effects. Fuel, 2007, 86(10-11), pp. 1534-1544. DOI 10.1016/ j.fuel.2006.11.006.

[34] SZYBIST, J.P., S. BUSCH, R.L. McCORMIC, P.A. PIHL, D.A. SPLITTER, M.A. RATCLIFF, C.P. KOLODZIEJ, J.M.E. STOREY, M. MOSES-DeBUSK, D. VUILLEUMIER, M. SJÖBERG, C.S. SLUDER, T. ROCKSTROH and P. MILES. What Fuel Properties Enable Higher Thermal Efficiency in SparkIgnited Engines? Progress in Energy and Combustion Science, 2021, 82, 100876. DOI 10.1016/j.pecs.2020.100876.

[35] MOURAD, M. and K. MAHMOUD. Investigation into SI Engine Performance Characteristics and Emissions Fuelled with Ethanol/Butanol-Gasoline Blends. Renewable Energy, 2019, 143, pp. 762-771. DOI 10.1016/j.renene.2019.05.064.

[36] Environmental Requirements for Liquid Fuels, Sustainability Criteria for Biofuels, Monitoring and Reporting Procedures for Liquid Fuels and Methodology for Determining Greenhouse Gas Emissions from the Use of Biofuels and Bioliquids [online]. 2010. Notification Number: 2021/126/EE [viewed 2020-1015]. Available from: https://ec.europa.eu/growth/tools-databases/tris/index.cfm/en/ search/?trisaction=search.detail\&year=2021\&num=126\&mLang=EN

[37] EL-DIN, M., M.R. MISHRIF, M. GAD and M. KESHAWY. Performance and Exhaust Emissions of a Diesel Engine Using Diesel Nanoemulsions as Alternative Fuels. Egyptian Journal of Petroleum, 2019, 28(2), pp. 197-204. DOI 10.1016/J.EJPE.2019.03.004.

[38] RAI, R.K. and R.R. SAHOO. Effective Power and Effective Power Density Analysis for Water in Diesel Emulsion as Fuel in Diesel Engine Performance. Energy, 2019, 180, pp. 893-902. DOI 10.1016/j.energy.2019.05.134.

[39] AATOLA, H., M. LARMI, T. SARJOVAARA and S. MIKKONEN. Hydrotreated Vegetable Oil (HVO) as a Renewable Diesel Fuel: Trade-off between NOx, Particulate Emission, and Fuel Consumption of a Heavy Duty Engine. SAE International Journal Engines, 2009, 1(1), pp. 1251-1262. DOI 10.4271/2008-01-2500.

[40] SOLMAZ, H., H. YAMIK, A. UYUMAZ, S. POLAT and E. YILMAZ. An Experimental Study on the Effects of Diesel and Jet-A1 Fuel Blends on Com- 
bustion, Engine Performance and Exhaust Emissions in a Direct Injection Diesel Engine. Journal of Thermal Science and Technology, 2016, 36(2), pp. 51-60. ISSN 1300-3615.

[41] RIMKUS, A., S. STRAVINSKAS and J. MATIJOŠIUS. Comparative Study on the Energetic and Ecologic Parameters of Dual Fuels (Diesel-NG and HVOBiogas) and Conventional Diesel Fuel in a CI Engine. Applied Sciences, 2020, 10(1), 359. DOI 10.3390/app10010359.

[42] GARRAIN, D., I. HERRERA, Y. LECHON and C. LAGO. Well-to-Tank Environmental Analysis of a Renewable Diesel Fuel from Vegetable Oil through CoProcessing in a Hydrotreatment Unit. Biomass and Bioenergy, 2014, 63, pp. 239-249. DOI 10.1016/j.biombioe.2014.01.035.

[43] KALETNIK, H., V. MAZUR, I. GUNKO, V. RYABOSHAPKA, V. BULGAKOV, V. RAIDE, R. ILVES and J. OLT. Study on Performance of Compression Engine Operated by Biodiesel Fuel. Agronomy Research, 2020, 18(S1), pp. 862887. DOI 10.15159/AR.20.027.

[44] HEYWOOD, J.B. Internal Combustion Engine Fundamentals. $2^{\text {nd }}$ ed. New York: McGraw-Hill Education, 2018. ISBN 978-1-260-11610-6. 